\title{
Institutional Conditions for Inclusive, Flood Resilient Urban Deltas: A Comparative Institutional Analysis of Two International Resilience Programs in Southeast Asia
}

\author{
Naim Laeni *(D), Margo van den Brink (D) and Jos Arts $(\mathbb{D}$ \\ Department of Spatial Planning and Environment, Faculty of Spatial Sciences, University of Groningen, \\ Groningen, Landleven 1, 9747 AD Groningen, The Netherlands; m.a.van.den.brink@rug.nl (M.v.d.B.); \\ jos.arts@rug.nl (J.A.) \\ * Correspondence: n.laeni@rug.nl; Tel.: +31-50-3633896
}

Citation: Laeni, N.; van den Brink, M.; Arts, J. Institutional Conditions for Inclusive, Flood Resilient Urban Deltas: A Comparative Institutional Analysis of Two International Resilience Programs in Southeast Asia. Water 2021, 13, 2478. https:// doi.org/10.3390/w13182478

Academic Editor: Piotr Matczak

Received: 5 August 2021

Accepted: 7 September 2021

Published: 9 September 2021

Publisher's Note: MDPI stays neutral with regard to jurisdictional claims in published maps and institutional affiliations.

Copyright: (C) 2021 by the authors. Licensee MDPI, Basel, Switzerland. This article is an open access article distributed under the terms and conditions of the Creative Commons Attribution (CC BY) license (https:/ / creativecommons.org/licenses/by/ $4.0 /)$.

\begin{abstract}
Policy makers in Southeast Asian flood-vulnerable regions are confronted with various institutional challenges when planning for inclusive flood resilience. This paper focuses on the role of international resilience programs and investigates how these programs can enable institutional transformation. The key question is which institutional conditions promote the development and implementation of inclusive flood resilience strategies by international resilience programs. The Mekong Delta Plan in Vietnam (MDP) and the Water as Leverage for Resilient Cities Asia (WaL) program in Semarang, Indonesia, are selected as the cases for a comparative analysis. To structure the comparative analysis of these programs, the Institutional Analysis and Development (IAD) framework is adopted and operationalized for the institutional analysis of inclusive flood resilience planning. The findings illustrate that whereas the MDP was able to involve decision makers from the national government and international financial institutions for mobilizing funding and technical support, the strength of the WaL program was its enabling environment for the cocreation of contextspecific flood resilience proposals. Overall, this study concludes that the institutional conditions that enable project financing and the implementation of long-term and integrated flood resilience solutions are determined by engagement with national governments and by ownership of the solutions at both the national and local levels.
\end{abstract}

Keywords: flood resilience; inclusive flood resilience; institutional analysis; institutional conditions; rules; international programs; southeast Asia

\section{Introduction}

Urbanized regions in southeast Asia are primarily located in flood-prone areas. Economic growth, rapid urbanization, ecological degradation, and urban migration are major forces of change that intensify the water-related challenges in these regions [1]. Policy makers and planners from national and local governments and experts are engaging in global policy networks for adopting flood resilience concepts in their planning practices [2-9]. Existing flood risk management approaches usually focus on the capacity to resist flooding, such as the construction of flood protection infrastructure. These approaches are currently being criticized for disregarding the social and ecological impacts of flood protection and for becoming less effective to cope with the current rapid changes in environmental and climate conditions $[2,9,10]$. The construction of flood protection measures could also lead to transferring flood risks to unprotected areas where the negative impacts are distributed to less advantaged communities [11,12]. Recent literature has therefore emphasized planning for flood resilience by diversifying flood risk management strategies, and thus investing in other types of measures including spatial flood adaptation, storm water management, community preparedness, and emergency flood responsiveness $[9,10,13]$. In this context, there is also a growing recognition that planning for flood resilience should not neglect the 
inclusive dimensions of resilience-building efforts, such as issues of justice, fairness, and equity [14-16]. As a result, there is increased attention in both literature and policy practice in addressing social inclusiveness issues in flood resilience building efforts $[9,11,15,17]$.

This paper aims to examine which institutional conditions promote the development and implementation of inclusive flood resilience strategies by international resilience programs. To this end, the paper presents a comparative institutional analysis of how two international resilience programs approached building inclusive flood resilience institutionally: the Mekong Delta Plan (MDP) in Vietnam and the Water as Leverage for Resilient Cities Asia (WaL) program in Semarang, Indonesia. To analyze the specific institutional arrangement of these programs, we adopted the Institutional Analysis and Development (IAD) framework developed by Ostrom [18]. The IAD framework provides an analytical tool to systematically examine the operational rules that govern the interaction among various actors in a multilevel governance setting $[19,20]$, and facilitates the analysis of the interaction and the conditions that are essential for institutional transformation [17,21,22]. Moreover, the IAD framework was selected because it was adopted to analyze the relational structure and negotiation process affecting the sustainable outcomes of international development assistance in developing countries [23,24]. Drawing on a theoretical exploration of the various 'rules-in-use' of the IAD framework [18,19,23], flood resilience literature $[5,17,22,25,26]$ and theoretical insights from Political Ecology literature [12,27-29], we developed a comparative framework for analyzing institutional conditions for improving inclusive flood resilience planning. We used this framework to examine the two selected international resilience programs in southeast Asia.

The remainder of this paper is organized as follows. The next section explains the Institutional Analysis and Development (IAD) framework, with a particular focus on rules-in-use. Section 3 presents the operationalization of the IAD framework for analyzing institutional conditions for inclusive flood resilience. Section 4 outlines the cases studied, the methods, and the developed analytical approach used. Section 5 provides a comparative institutional analysis of the MDP in Vietnam and the WaL program in Semarang, and presents the similarities and differences between these two international resilience programs. In Section 6, we provide an overview of the institutional strengths and weaknesses of the two programs. Based on this overview, we also present key recommendations for the future development of the structure and organization of international resilience programs. This paper ends with the conclusions of the key findings and suggestions for future research.

\section{An Institutional Approach: Rules-in-Use}

The IAD framework has been applied widely in policy, governance, and institutional studies $[20,21,23,24,30-33]$. The framework was initially developed to analyze the structure and process of interactions between policy actors to achieve efficient and sustainable use of common-pool resources in multilevel and polycentric governance settings [34]. According to Ostrom [19], the aim was to develop a systematic approach that contains a set of variables that reflect the complexity of policy interaction-the action-situation. The IAD framework thus provides "a set of building blocks that social scientists can use in efforts to understand human interactions and outcomes across diverse settings" [18]. The core analytical concept of the IAD framework is the action-situation, which is used to explain and predict the patterns, actions and interactions that determine policy outcomes [35]. Action-situations are "social spaces where individuals interact, exchange goods and services, solve problems, dominate one another, or fight (among the many things that individuals do in action situations)" [19]. These action-situations can be affected by rules-in-use [19]. According to Clement [20], a key assumption of the IAD framework is that the behavior of actors can be modified, in particular, by changing the rules-in-use, thereby enabling or constraining the structure of interaction (see Figure 1). 


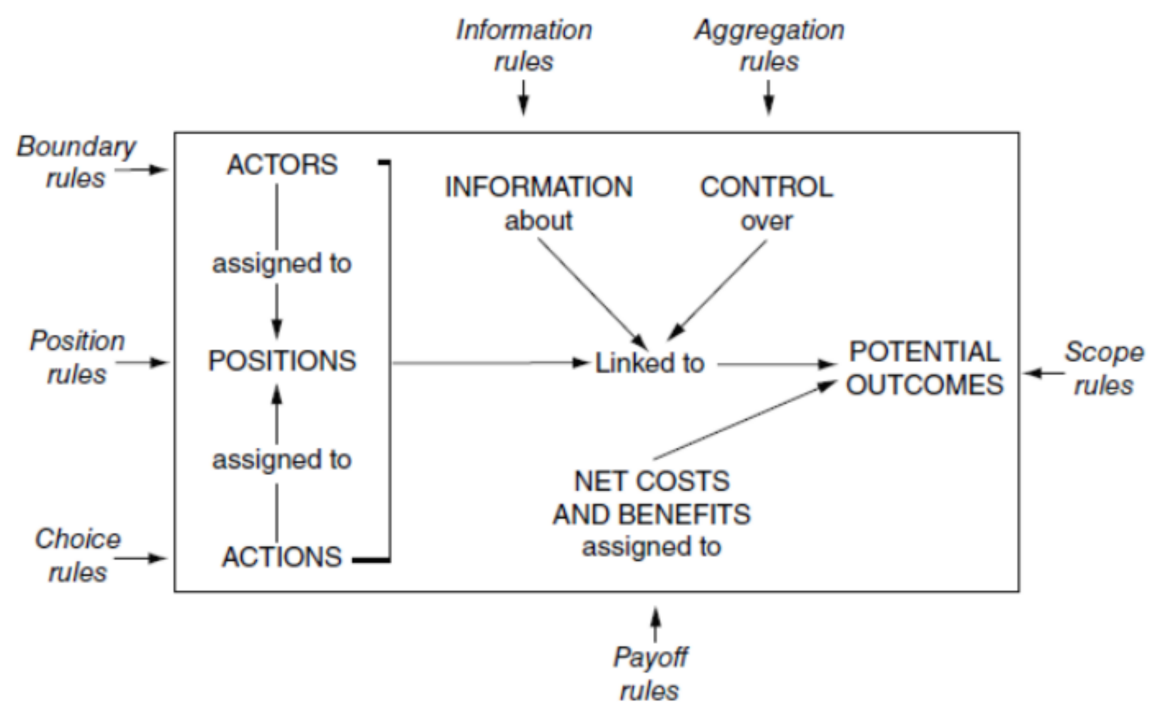

Figure 1. Rules-in-use affecting the structure and elements in an action-situation as developed by Ostrom (2010).

Rules-in-use are important in an institutional analysis as they specify a common understanding of which actions actors must, must not or may take [35]. Ostrom et al. [23] initially used rules-in-use as a general guide to analyze how the negotiation process and the relationship between donor and recipient countries affect agreement upon the feasibility and sustainability of an international development project, which is quite similar to the focus of our paper. To understand the institutional arrangement of an international resilience program, we analyzed the structure of the action-situation based on the seven rules-in-use defined by Ostrom [19], as shown in Figure 1. Boundary rules specify which actors are involved in the action arena and how they enter and leave the action arena, and thus concern how these actors are invited or selected to be part of an action-situation. These rules also set the number and characteristics of participants in an action situation. Position rules identify the sets of positions that are assigned to the actors involved. These rules reflect the capabilities and responsibilities of the actors in the assigned positions, defining who can act as a regulator, promoter or supporter in the action situation. Choice rules specify the possible actions that actors are allowed, obliged or prohibited to take. These rules thus concern the choices of allowable actions for actors to take according to their roles and tasks. Scope rules determine the intended outcome that may, must, or must not occur. These rules can be related to framing and clarifying the policy goals in the planning process, such as water safety and spatial and ecological quality. Aggregation rules affect how decisions about actions and activities can jointly be made by actors. These rules also determine where the decisions come from, for example, national government or local government, and whether there will be opportunities for 'marginalized' groups to take part in decision-making. Information rules specify the essential conditions of how the information is made available to, sent to and received by the actors. These rules also reflect how information facilities and activities such as meetings, seminars, events, and workshops could be organized. Finally, Payoff rules determine the benefits and costs that have to be distributed, paid and received by the actors involved. The payoff rules consider the important question of how funding is guaranteed, mobilized, and activated.

\section{Operationalizing Rules-in-Use for the Institutional Analysis of Inclusive Flood Resilience Planning}

In this section, we operationalize the rules-in-use that are part of the IAD framework $[18,19]$ for the analysis of essential institutional conditions set or induced by international resilience programs for the development and implementation of inclusive 
flood resilience strategies (see Table 1). We thus draw on insights from flood resilience literature $[3-5,10,21,25,36-38]$ to further operationalize the seven rules-in-use for analyzing the institutional conditions introduced by international programs to build inclusive flood resilience.

Boundary rules specify which actors can enter and participate in the international resilience programs. The default condition of boundary rules is that anyone can enter into an action-situation [35]. As addressed by various authors [15,17,26,37], building flood resilience requires a broad engagement and consultation among various actors from different professions, organizations, and interests to jointly develop flood resilience solutions. The first essential institutional condition for inclusive flood resilience is, therefore, connecting diverse experts and policy makers; for instance, in water management, spatial planning, ecology, and urban design. Restemeyer et al. [3] highlight the importance of collaboration between water experts and spatial planners for specific spatial adaptation projects such as creating more space for water. The second essential condition is involving local stakeholders such as local communities, universities and NGOs, and to facilitate social acceptance in decision-making $[9,11]$. The third and last essential condition is engaging with financial institutions and decision-makers from governmental agencies across sectors and administrative levels. The involvement of official decision-makers proves an important consideration in the structuring and organizing of international resilience programs as this often determines the translation of preferable solutions to proposal development and project implementation [39].

Position rules identify the important capacities and possible roles of the involved actors needed for institutional transformation. The default condition of these rules is that no formal positions exist in the action situation. Various authors $[15,17,22,25]$ who have discussed flood resilience have stressed the importance of networks of actors with capacities to contribute ideas and to develop flood resilience strategies. In this context, there are different roles important when building inclusive flood resilience, which can be translated into essential conditions. The promoter is the first essential role. It stresses the ability of actors to support the reframing of flood problems and to develop proactive and integrated flood risk management strategies [16,17]. The second role is that of the connector, which places emphasis on the ability of actors to link the developed inclusive and integrated solutions to the formal planning and policy making process. The connecting role includes the development of visions and strategies together with decision-makers and exploits opportunities to embed the solutions in different issues and agendas across policy boundaries [40]. Gersonius et al. [25] also stressed the importance of the position of involved actors to influence policy change in a formal institutional context such as supporting the implementation of flood resilience strategies in practice. The third and last role is the facilitator role that emphasizes the importance of the ability of actors to support collaboration across multiple stakeholders from the government, private sectors, knowledge institutions and local communities. Participants in international resilience programs should, therefore, be able to communicate with a wide range of stakeholders to enable the adoption of new policy initiatives and stimulate long-term institutional change $[3,10,37]$.

Choice rules describe the allowable actions and opportunities of the participants to take action in the international resilience programs. According to Ostrom and Basurto [35], the default condition regarding the choice rules is that any actor can take possible actions in the action-situation. For planning for inclusive flood resilience, international resilience programs need to create an enabling environment for participants to support, develop and implement proactive and integrated flood resilience solutions $[25,38]$. The first essential condition is supporting the learning process and experimentation with new solutions. As Hegger et al. [5] argue, the flood resilience approach calls for diversifying strategies in flood risk management, including flood prevention, flood defense, flood mitigation, flood preparation and flood recovery. Promoting such strategies requires the joint commitment of international resilience programs and local policy makers to support the development 
of these strategies, to improve the planning process and to foster institutional change by learning about and experimenting with the new flood resilience solutions. The second essential condition is developing proactive and long-term flood risk management strategies and measures. According to Handayani et al. [7], the translation of flood resilience into planning practices should enable local policy makers to develop proactive measures rather than relying on short-term reactive responses. In this context, the diverse flood resilience strategies should take into account the strengths and weaknesses of the specific physical and institutional contexts $[4,10,15,25,29]$. The third and last essential condition is integrating the implementation of the developed flood resilience strategies in broader spatial visions and strategies. The alignment of short-term actionable initiatives with broader and integrated spatial visions must be taken into consideration $[7,9]$.

Scope rules determine the anticipated outcomes from the actions of the involved actors in international resilience programs. The default condition of these rules is that any actor can affect the state of outcomes and interaction [35]. The translation of the resilience concept to planning practice, as developed by Davoudi [36], emphasized robustness, adaptability, and transformability as important outcomes when planning for flood resilience $[3,41]$. The first essential condition, robustness, is to achieve flood safety and protection [5]. While protection and safety from increasing flood risks generally appear to be dominant in flood risk management, planning for inclusive flood resilience also calls for strategies to strengthen the capacities for flood adaptation and recovery and for promoting societal learning and innovation $[25,30]$. Therefore, the second essential condition, adaptability, is realizing flood adaptation and flood recovery [3]. The third essential condition, transformability, is to promote societal learning based on local and international experience and for fostering institutional change and innovation [8,42].

Aggregation rules affect the modes of decision-making for reaching an agreement and the selection of courses of action. These rules determine which actions or activities are to be taken and in what ways these options can be implemented. The default condition of these rules is that each actor can have a different effect on the outcome of interaction and action. In the context of international development programs, Ostrom et al. [23] highlighted that the local commitment and sustainability of an international development program are higher when the beneficiary country is a real owner of the program and has an active role in the process. It is therefore important that the decision-making process includes the interests of and creates opportunities to cocreate solutions with local partners and involved communities [11,15]. The first essential condition, therefore, is involving the relevant parties, including the policy makers and local communities in decision-making. Decisions in setting up, structuring, and implementing the international development programs should be made collaboratively with local actors. The second essential condition is enabling cocreation processes to stimulate local ownership of flood resilience solutions. In this context, Anderies [22] emphasizes that building flood resilience is more effective when decision-makers and independent policy actors can interact with and learn from each other. The third essential condition is identifying opportunities to integrate flood resilience solutions in the formal institutional context. The decision-makers should be well informed and continuously involved in the decision-making for identifying, selecting, and formulating flood resilience strategies [39]. According to Gersonius et al. [25], flood resilience strategies could not be realized without the ability to integrate flood resilience in various policy domains and across administrative levels.

Information rules are essential to specify the information needed for participants to achieve inclusive outcomes from flood resilience planning. The default condition for information rules is that each actor can communicate freely via any channel available to them. Open communication and interaction between stakeholders are important to build trust and shared-understanding for mobilizing resources $[15,17]$. The first essential condition for information rules is, therefore, open communication and continuous dialogue between participants and stakeholders throughout the planning process. The second condition is adopting and integrating scientific insights, local knowledge and innovative 
ideas, as the integration of interdisciplinary knowledge and local insights could help to foster innovative ideas and long-term solutions [3,8]. It is important for participants to have access to information about problems and solutions, and to use scientific insights and new knowledge to address flood problems [38]. The third essential condition is raising flood awareness by increasing understanding about the physical, social and, environmental vulnerabilities of the local context [28]. Here, international resilience programs could play a key role in sharing different types of knowledge and insights for raising awareness on flood risks and climate impacts among decision-makers and stakeholders.

Payoff rules determine the distribution of costs and benefits of the actions and outcomes from the building of inclusive flood resilience. Ostrom and Basurto [35] explained that the default condition for payoff rules is when any actor can obtain and defend outcomes from their actions. In building flood resilience, Driessen et al. [9] stressed that the assurance of financial and other resources for the development and implementation of flood risk management strategies is an essential precondition. The first essential condition regarding the distribution of benefits and costs is, therefore, identifying and communicating about funding availabilities and opportunities for realizing inclusive flood resilience strategies. The second condition is supporting the mobilization of funding for proposal development and project financing, including how the various sources of funding can be identified, such as from the national government, international financial institutions, and international development assistance. The third and last essential condition is ensuring social and ecological outcomes and the benefit of communities in the project implementation. Various authors have indicated that inclusive and integrated dimensions, such as social, ecological, and cultural benefits for communities, should be addressed, along with achieving flood safety and protection $[4,12,14,21,37]$. The payoff rules also concern who will benefit from the international resilience programs. Ostrom et al. [23] illustrated that several actors, such as contractors, civil society organizations, aid and governmental agencies, and local communities, can potentially benefit from the financing and implementation of international development programs. International resilience programs should, therefore, facilitate the financial investment in holistic and integrated flood resilience initiatives to respond to flood and ecological risks in the local context.

Table 1. Operationalizing rules-in-use for the institutional analysis of inclusive flood resilience planning.

\begin{tabular}{|c|c|c|c|}
\hline Rules-in-Use & Default Condition & Essential Conditions for Inclusive Flood Resilience & References \\
\hline 1. Boundary rules & Anyone can enter & $\begin{array}{l}\text { - Connecting diverse experts and policy makers } \\
\text { from various disciplines and sectors including } \\
\text { water management, spatial planning, ecology and } \\
\text { urban design. } \\
\text { Involving local stakeholders such as communities, } \\
\text { universities, NGOs, and interest groups. } \\
\text { - Engaging financial institutions, international } \\
\text { organizations, and decision-makers from } \\
\text { governmental agencies across sectors and } \\
\text { administrative levels. }\end{array}$ & $\begin{array}{c}\text { Molenveld and van } \\
\text { Buuren [17]; Sörensen et al. } \\
\text { [37]; Driessen et al. [38]; } \\
\text { Restemeyer et al. [3]; } \\
\text { Lebel et al. [15]; Laeni } \\
\text { et al. [43]; Wiering et al. } \\
\text { [26]; Alexander et al. [11] }\end{array}$ \\
\hline 2. Position rules & $\begin{array}{c}\text { No formal } \\
\text { positions exist }\end{array}$ & $\begin{array}{l}\text { - Promoting the reframing of flood problems and } \\
\text { identifying integrated and proactive long-term } \\
\text { flood risk management strategies. } \\
\text { Connecting integrated and proactive long-term } \\
\text { solutions to formal policy, planning, } \\
\text { and implementation. } \\
\text { Facilitating collaboration across multiple } \\
\text { stakeholders from government, private sectors, } \\
\text { knowledge institutions, and local communities. }\end{array}$ & $\begin{array}{c}\text { Anderies [22]; Driessen } \\
\text { et al. [38]; Gersonius et al. } \\
\text { [25]; Alexander et al. [11]; } \\
\text { Rosenzweig et al. [10]; } \\
\text { Lebel et al. [15]; } \\
\text { Molenveld and van } \\
\text { Buuren [17]; van den Brink } \\
\text { et al. [40]; Restemeyer et al. } \\
\text { [3]; Sörensen et al. [37] }\end{array}$ \\
\hline
\end{tabular}


Table 1. Cont.

\begin{tabular}{|c|c|c|c|}
\hline Rules-in-Use & Default Condition & Essential Conditions for Inclusive Flood Resilience & References \\
\hline 3. Choice rules & $\begin{array}{l}\text { Any actor can take } \\
\text { any possible action }\end{array}$ & 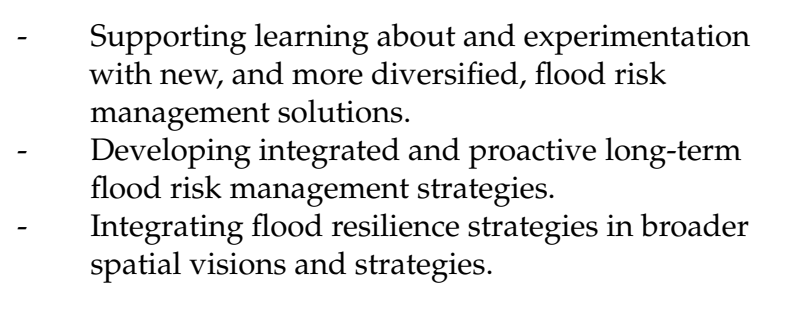 & $\begin{array}{c}\text { Molenveld and van } \\
\text { Buuren [17]; Alexander } \\
\text { et al. [11]; Gersonius et al. } \\
\text { [25]; Driessen et al. [38]; } \\
\text { Hegger et al. [5]; } \\
\text { Handayani et al. [7]; Liao } \\
\text { [4]; Rosenzweig et al. [10]; } \\
\text { Keil [29] }\end{array}$ \\
\hline 4. Scope rules & $\begin{array}{l}\text { Each actor can } \\
\text { differently affect } \\
\text { the outcome of } \\
\text { interaction } \\
\text { and action }\end{array}$ & $\begin{array}{l}\text { - Achieving flood safety and protection } \\
\text { ('robustness'). } \\
\text { - Striving for flood adaptation and recovery } \\
\text { ('adaptability'). } \\
\text { Promoting societal learning and long-term } \\
\text { capacity building for fostering institutional change } \\
\text { and innovation ('transformability'). }\end{array}$ & $\begin{array}{l}\text { Davoudi [36]; Alexander } \\
\text { et al. [11]; Restemeyer } \\
\text { et al. [3]; Lebel et al. [44]; } \\
\text { Folke et al. [41]; Hegger } \\
\text { et al. [5]; Gersonius et al. } \\
\text { [25]; van den Hurk et al. } \\
\text { [30]; Kuang and Liao [8]; } \\
\text { Pahl-Wostl et al. [42] }\end{array}$ \\
\hline $\begin{array}{l}\text { 5. Aggregation } \\
\text { rules }\end{array}$ & $\begin{array}{c}\text { Actors act } \\
\text { independently }\end{array}$ & $\begin{array}{l}\text { - Involving key policy makers, and local } \\
\text { communities in decision-making about goals and } \\
\text { activities. } \\
\text { Enabling cocreation processes to stimulate local } \\
\text { ownership of flood resilience solutions. } \\
\text { - } \quad \text { Identifying opportunities to integrate flood } \\
\text { resilience solutions in formal planning practice. }\end{array}$ & $\begin{array}{c}\text { Ostrom et al. [23]; } \\
\text { Alexander et al. [11]; Lebel } \\
\text { et al. [15]; Anderies [22]; } \\
\text { Gersonius et al. [25] }\end{array}$ \\
\hline $\begin{array}{l}\text { 6. Information } \\
\text { rules }\end{array}$ & $\begin{array}{l}\text { Each actor can } \\
\text { communicate any } \\
\text { information via } \\
\text { any channel } \\
\text { available to } \\
\text { the actor }\end{array}$ & $\begin{array}{l}\text { - Enabling open communication and continuous } \\
\text { dialogue for building trust and } \\
\text { shared-understanding. } \\
\text { Integrating scientific insights, local knowledge, } \\
\text { and innovative ideas. } \\
\text { Raising flood awareness among decision-makers } \\
\text { and stakeholders. }\end{array}$ & $\begin{array}{l}\text { Lebel et al. [15]; } \\
\text { Molenveld and van } \\
\text { Buuren [17]; Kuang and } \\
\text { Liao [8]; Restemeyer et al. } \\
\text { [3]; Driessen et al. [38]; } \\
\text { Furedi [28] }\end{array}$ \\
\hline 7. Payoff rules & $\begin{array}{l}\text { Each actor can } \\
\text { retain any possible } \\
\text { costs and benefits }\end{array}$ & $\begin{array}{l}\text { - } \quad \begin{array}{l}\text { Identifying funding availabilities and } \\
\text { opportunities. }\end{array} \\
\text { - } \quad \text { Supporting the mobilization of funding for } \\
\text { proposal development and project financing. } \\
\text { - } \quad \text { Ensuring social, ecological, and cultural benefits } \\
\text { for communities in the project implementation. }\end{array}$ & $\begin{array}{l}\text { Driessen et al. [9]; Ostrom } \\
\text { et al. [23]; Liao [4]; } \\
\text { Sörensen et al. [37]; Vitale } \\
\text { et al. [21]; Marks [12]; } \\
\text { Marks and Elinoff [14] }\end{array}$ \\
\hline
\end{tabular}

\section{Methodology}

4.1. Cases

This paper focuses on two international resilience programs as action-situations for the translation of and cross-border learning in water policy: the Mekong Delta Plan (MDP) in Vietnam and the Water as Leverage for Resilient Cities Asia (WaL) program as applied in the city of Semarang in Indonesia.

\subsubsection{Mekong Delta Plan (MDP)}

The first case study is the Mekong Delta Plan (MDP) in Vietnam. The formulation of the MDP was completed in 2013, which was the result of the bilateral water cooperation between the Vietnamese and Dutch governments (Government of the Netherlands and Government of Vietnam, 2013). The MDP was developed by a group of Dutch experts and consultants and Vietnamese former civil servants and experts [45] The MDP serves as a strategic recommendation, which sets socio-economic scenarios and recommends strategic 
delta measures under the motto 'toward a resilient urban delta' in Vietnamese delta and water management, suggesting transitioning towards an 'agro-business industrialization scenario' (see Figure 2). This scenario is illustrated in the Figure 2, which highlights the future development of Vietnamese delta management to overcome existing stresses in water resources and land use management. This development path requires well-coordinated planning and high-tech agriculture development. Although the document was not formalized in the Vietnamese administrative systems, the strategic recommendations from the MDP resonated among international development parties and provided a reference for the upcoming delta development projects with international funding (such as Government Resolution 120 on Climate-Resilient Mekong Delta). This paper focuses on the development and implementation of the MDP as the action-situation for the policy transformation to resilient delta management. The MDP is the first Delta Plan developed outside the Netherlands and is based on the Dutch Delta Program 2008.

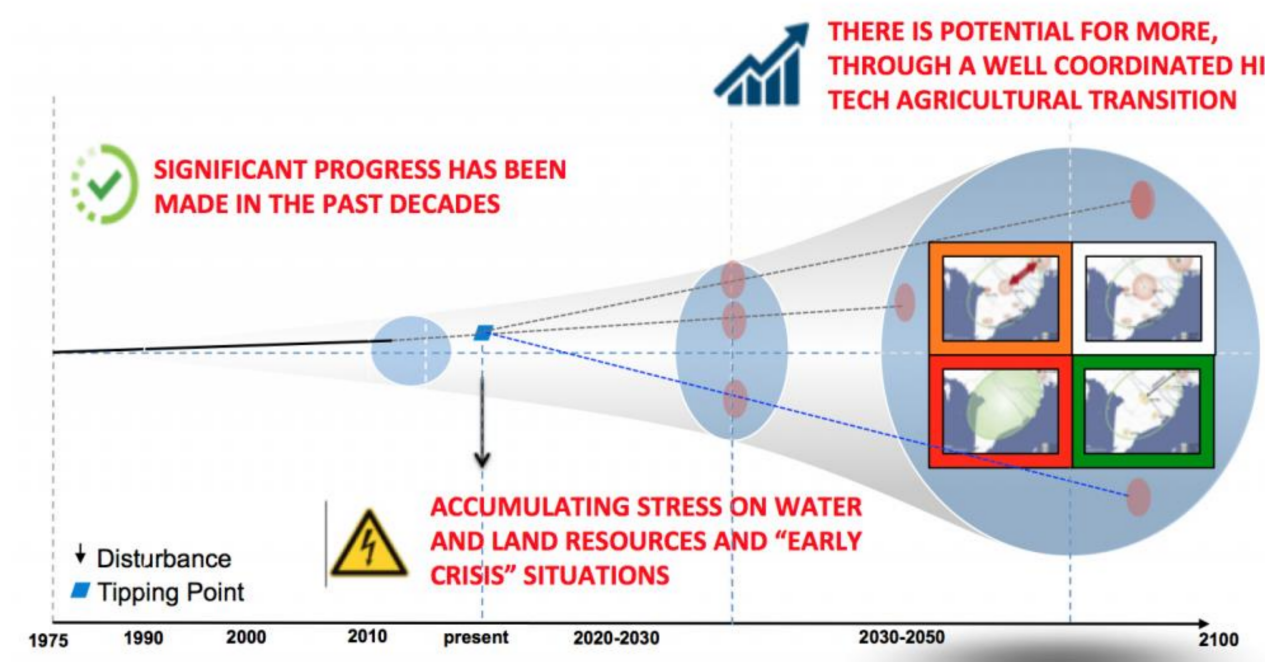

Figure 2. Strategic recommendation towards agro-business industrialization in the MDP 2013 (Source: www. mekongdeltaplan.com). Accessed on 1 December 2020.

\subsubsection{Water as Leverage for Resilient Cities Asia (WaL) Program}

The second case study is the Water as Leverage for Resilient Cities Asia (WaL) program. The WaL program focused on the design and cocreation of proactive and integrated climateresilience solutions (see Figure 3) and can be considered the first application of a design-led planning approach in the context of Asian cities [39,43]. While the program was initiated and funded by the Dutch government, its implementation was in collaboration with several international development partners such as UN-Habitat, the 100 Resilience Cities Program, AIIB, ADB and WWF. The main aims of the program included: identifying catalytic and innovative urban climate resilience solutions, stimulating collaboration and capacitybuilding processes, and creating opportunities for integrated climate financing [46]. The program was implemented in three pilot cities in Asia: Chennai, India; Khulna, Bangladesh; and Semarang, Indonesia. This paper focuses on the development of the WaL program in Semarang. This city has been part of various international resilience programs because of its growing urban and water-related challenges. With existing experience among the city's policy makers and academics in international collaboration, Semarang also has the potential to engage in a design-led type of approach for strengthening their urban flood resilience planning. In this city, two multidisciplinary design teams were selected to participate in the resilience-by-design process, namely 'One Resilient Semarang' and 'Cascading Semarang' [47]. The teams engaged in design-based research in the local 
context and development of climate solutions with local stakeholders [47,48], and presented strategic climate resilience proposals: six diverse programmatic approaches or solutions for addressing flood risks and water challenges in Semarang. The proposals were (1) WaterNeutral Industry, (2) Feeding Industry, (3) Network of Resilience Kampungs, (4) Integrated Protective Coastal Zone, (5) Spongy Mountain Terraces, and (6) Rechanneling the City. At the time this paper was written, the WaL program teams and the multidisciplinary design teams were working on translating the conceptual program designs into proposal developments for implementation.

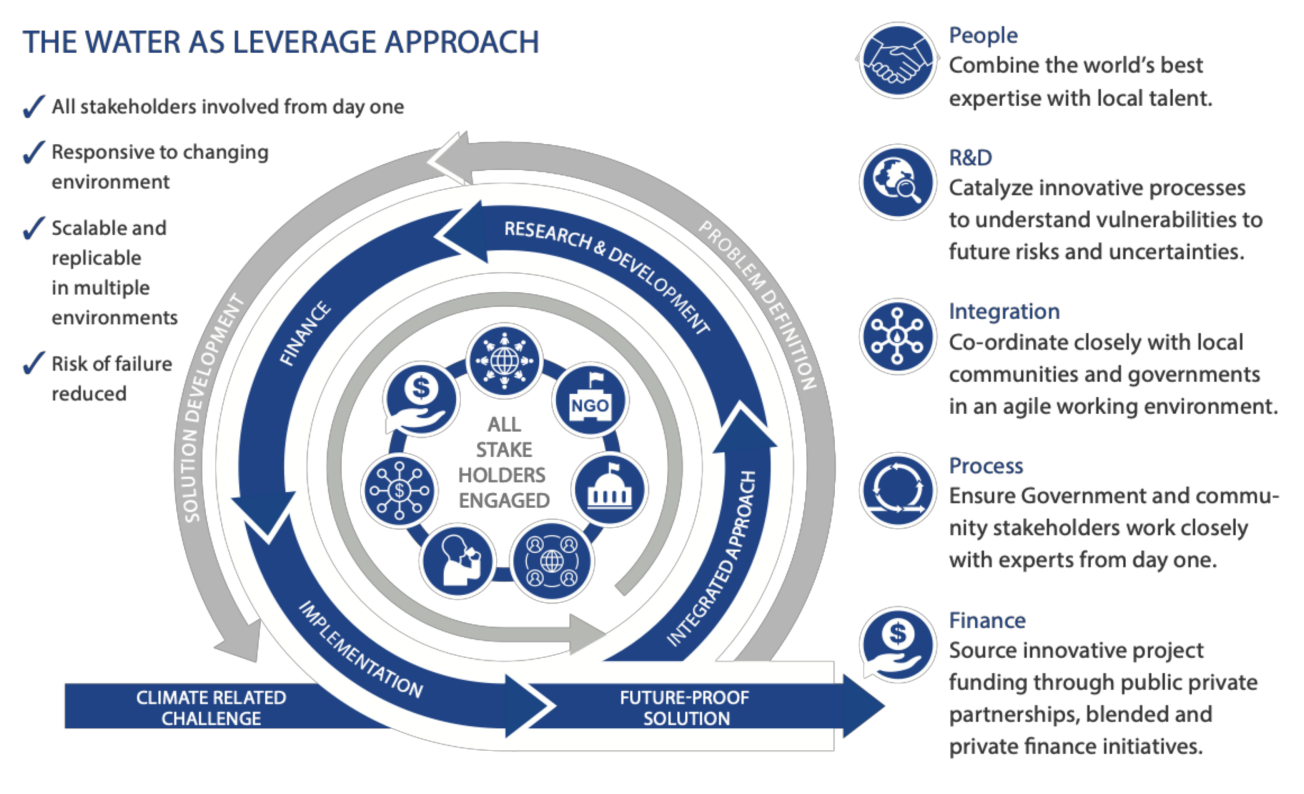

Figure 3. Water as Leverage Approach (Source: Water as Leverage program 2019).

\subsection{Data Collection and Analysis}

We used the operationalization of the rules-in-use for building inclusive, urban flood resilience, as presented in Table 1, for the comparative institutional analysis of the MDP and the WaL program. Empirical data collection was based on a combination of document analysis and in-depth interviews for both case studies. For the MDP case, we used policy documents, reports and official plans related to the formulation and implementation of the MDP 2013. We conducted a total of 10 in-depth semistructured interviews with policy officials, diplomats, academics and consultants who were directly involved in the development of the MDP (see Table 2). For the WaL case, we analyzed various program reports, pamphlets and guidelines developed and produced by the WaL program. During the fieldwork data collection in Semarang, we also conducted 12 in-depth semistructured interviews with the WaL program teams, local policy officials, local and international urban designers and planners, government representatives, local NGOs, and community leaders (see Table 2). For both cases, the interviews were structured with three main focuses: the organization of the programs, the involvement of various parties, and how the programs were perceived by local stakeholders (challenges and opportunities).

For the analysis, we used Atlas.ti 8 textual analysis software to compile the documents, develop a deductive coding scheme based on the analytical framework (see the code network in the Appendix A), and to code all the primary data from both the documents and the interviews. We used two separate hermeneutic units of the Atlas.ti files for each case study. We first used the coding scheme to analyze the data set (interviews and documents) for the MDP case and the WaL case. We then exported the coding reports from each case study for the comparative analysis of each rule based on our operationalization 
of the rules-in-use (Table 1). For both cases, we also used key insights and findings relevant to recently published literature $[45,49-52]$ to strengthen our analysis.

Table 2. Overview of documents and interviews for the data collection.

\begin{tabular}{|c|c|}
\hline \multicolumn{2}{|c|}{ Primary Data for Mekong Delta Plan Case } \\
\hline \multirow[b]{3}{*}{ Documents } & Interviews \\
\hline & $\begin{array}{l}\text { 1. Senior Project Manager Rivers and Coast (Royal } \\
\text { HaskoningDHV) }\end{array}$ \\
\hline & 2. Strategic Advisor at the Dutch Ministry of Infrastructure \\
\hline 1. The Delta Program (2008) & $\begin{array}{l}\text { and Water Management (Former First Secretary Water and } \\
\text { Climate Dutch Embassv in Vietnam) }\end{array}$ \\
\hline $\begin{array}{l}\text { 2. Converging Streams-An International Water Ambition, } \\
\text { Dutch Framework Cooperation (2016) }\end{array}$ & 3. Delta Coordinator for International Water Policy unit \\
\hline 3. The Mekong Delta Plan (2013) & (Dutch Ministry of Infrastructure and Water Management) \\
\hline $\begin{array}{l}\text { 4. Mekong Delta Integrated Climate Resilience and } \\
\text { Sustainable Livelihood Project (2016) }\end{array}$ & 5. Post-doctoral researcher (Water System and Global \\
\hline Project Appraisal Document for Mekong Delta Integrated & $\begin{array}{l}\text { Change, Wageningen University and Research) } \\
\text { Water Secretary at Dutch Embassy Hanoi }\end{array}$ \\
\hline Climate Resilience and Sustainable Livelihood Project & Climate Change expert and Director (Climatesense.eu) \\
\hline $6 \quad$ (2016) & 8. Independent Urban Delta Researcher and Journalist \\
\hline Development of the Mekong Delta Vietnam (2017) & $\begin{array}{l}\text { 9. Manager Water Resources Department (Royal } \\
\text { HaskoningDHV Vietnam) }\end{array}$ \\
\hline & $\begin{array}{l}\text { 10. Deputy Director of Environmental and Natural Resources } \\
\text { (Research Institute for Climate Change, Can Tho } \\
\text { University) }\end{array}$ \\
\hline
\end{tabular}

Primary data for Water as Leverage program case

\section{Interviews}

1. UN-Habitat Urban Design Lead

2. Technical Advisor for Chief Resilience Officer Semarang and Lecturer (Diponegoro University)

3. Program Director and member of One Resilient team (Kota Kita-Our City Foundation)

4. Landscape Architect and consortium design lead of Cascading Semarang Team (MLA+)

\section{Documents}

1. Factsheet Water as Leverage (2019)

2. Water as Leverage for Transformative Impact (2017)

3. Water as Leverage Semarang-One page two teams (2019)

4. WAL Call for Action Guideline (2018)

5. Setting the Scene For a Call For Action (2015)

6. A Table of Netherlands-Indonesia MOU Water Cooperation (2019)
5. Landscape Architect and consortium design lead of One Semarang Team (One Architecture and Urbanism)

6. Program Advisor Global Public Goods (Netherlands Enterprise Agency)

7. Head of Infrastructure and Environment Research and Development (Semarang Planning Agency)

8. Dutch International Water Envoy (Ministry of Infrastructure and Water Management)

9. Program Manager (The Indonesia Association for Sustainable Development-Bintari Foundation)

10. Dutch government representative for Water Cooperation Netherlands-Indonesia

11. Resource Mobilization Director (Indonesia Science Fund)

12. Senior Project Manager and member of the Cascading team (Deltares)

\section{Comparative Institutional Analysis of the MDP and the WaL Program}

This section presents the comparison between the rules-in-use in the two selected case studies: the MDP in Vietnam and the WaL program in Semarang, Indonesia. For each rule, we first explain the similarities in institutional conditions between the two programs. We then discuss the differences in institutional conditions for enabling inclusive flood 
resilience. This section is concluded with an overview of the essential conditions that resulted from each program (see Table 3).

Table 3. The essential institutional conditions based on the rules-in-use derived from the MDP and the WaL program.

\begin{tabular}{|c|c|c|}
\hline Rules & Mekong Delta Plan (MDP) & Water as a Leverage Program (WaL) \\
\hline 1. Boundary rules & $\begin{array}{c}\text { The involvement of experts, policy makers from } \\
\text { national levels, and various international } \\
\text { development organizations and financial } \\
\text { institutions. }\end{array}$ & $\begin{array}{l}\text { The involvement of the multidisciplinary design } \\
\text { teams which comprised of members from various } \\
\text { professional backgrounds, academics, NGOs, and } \\
\text { government. }\end{array}$ \\
\hline 2. Position rules & $\begin{array}{c}\text { The participants have a strong role as 'connectors' } \\
\text { to translate strategic recommendations into the } \\
\text { formal policy making process. }\end{array}$ & $\begin{array}{l}\text { The participants were assumed a 'facilitator' role } \\
\text { in building the social relation and forming local } \\
\text { coalition between the international experts and } \\
\text { local design team members and stakeholders. }\end{array}$ \\
\hline 3. Choice rules & $\begin{array}{l}\text { The MDP provided strategic recommendations } \\
\text { based on scenario analysis and expert insights for } \\
\text { adapting the country's current agricultural practice } \\
\text { by promoting the investment in aquaculture and } \\
\text { saline-based agriculture development. }\end{array}$ & $\begin{array}{l}\text { The WaL program developed strategic climate } \\
\text { resilience proposals—six conceptual } \\
\text { designs-with specific flood resilience measures at } \\
\text { the city scale. }\end{array}$ \\
\hline 4. Scope rules & $\begin{array}{l}\text { The MDP aimed to strengthen adaptability and } \\
\text { transformability outcomes by introducing new } \\
\text { agricultural practices that adapt to salination and } \\
\text { by promoting integrated flood risk management } \\
\text { through scenario planning and coordination } \\
\text { between agencies. }\end{array}$ & $\begin{array}{l}\text { The WaL program aimed to introduce } \\
\text { resilience-by-design and urban water resilience } \\
\text { solutions for achieving robustness, adaptability, } \\
\text { and transformability outcomes. }\end{array}$ \\
\hline 5. Aggregation rules & $\begin{array}{c}\text { Decisions in the formulation and implementation } \\
\text { of the MDP were driven by experts, academics, } \\
\text { and policy officials from the ministries. The plan } \\
\text { was enforced and coordinated by the national } \\
\text { government. }\end{array}$ & $\begin{array}{l}\text { The decision-making in the WaL program is based } \\
\text { on a bottom-up and cocreation process that } \\
\text { emphasizes building of social coalition and } \\
\text { strengthening participation of local communities. }\end{array}$ \\
\hline 6. Information rules & $\begin{array}{l}\text { The identification of problems and solutions } \\
\text { created by the MDP was based on integrating } \\
\text { expert insights, systematic analysis, and adopting } \\
\text { strategic recommendations from the experience } \\
\text { and lessons from Dutch delta management. }\end{array}$ & $\begin{array}{l}\text { The identification of problems and solutions } \\
\text { creation from the WaL program was based on } \\
\text { sharing insight and knowledge from international } \\
\text { examples and experience, and open dialogue and } \\
\text { communication between the multidisciplinary } \\
\text { design teams and local stakeholders. }\end{array}$ \\
\hline 7. Payoff rules & $\begin{array}{l}\text { The national government partners secured } \\
\text { financial loans from the World Bank with } \\
\text { conditions to ensure the social and ecological } \\
\text { benefits in the implementation of insights and } \\
\text { recommendation from the MDP. }\end{array}$ & $\begin{array}{l}\text { The local coalition of the WaL program still needs } \\
\text { to acquire a political buy-in of the flood resilience } \\
\text { proposals at the national government to activate } \\
\text { the project financing, development and } \\
\text { implementation process. }\end{array}$ \\
\hline
\end{tabular}

\subsection{Boundary Rules}

To begin with, both the MDP and the WaL program were initiated by the Dutch government in collaboration with the government of the beneficiary countries, international development organizations, and international financial institutions. This is an important similarity in the boundary rules between both programs, relating to the essential condition to engage with international organizations and governmental decision-makers. The development and the implementation of the MDP involved Dutch experts and consultants, Dutch diplomats at the Dutch Embassy in Hanoi, Dutch policy officials at the Ministry of Infrastructure and Water Management, Vietnamese academics, and retired civil servants and representatives from the Vietnamese ministries including the Ministry of Natural Resources and Environment (MONROE) and the Ministry of Agriculture and Rural Development (MARD). In Semarang, the WaL program was initiated and organized by the Dutch government (the Netherlands Enterprise Agency, RVO) in collaboration with the city government of Semarang and Semarang Planning Agency [46]. Another similarity was that both programs also involved international organizations in the set-up and implementation of the programs. To give an example, the formalization and implementation of MDP was 
supported by the World Bank and other international development organizations such as UNDP, the World Bank, the Asian Development Bank (ADB), the German Development Agency (GIZ), and the International Union for Conservation of Nature (IUCN). The WaL program was initiated in collaboration with several international organizations such as the WWF, UN-Habitat, the Green Climate Fund and the Asian Development Bank. These international organizations were involved in the WaL design workshops, local workshops, and regional workshops and gave feedback to the design teams in the development of the strategic climate resilience proposals [46].

Regarding the differences in the boundary rules, the WaL program connected a wide range of policy actors and experts from more diverse sectors and disciplines through the resilience-by-design process. During the design contest, the two selected design teams, 'One Semarang' and 'Cascading Semarang', were formed by a diverse group of professions and backgrounds including urban designers, landscape architects, engineers, water experts, and urban planners from both local and international organizations [53]. The WaL program also engaged with various international financial institutions in an earlier stage of the program. The World Bank was involved in the MDP after the plan was launched. Furthermore, the WaL program engaged more local actors while the policy makers involved in the MDP were mainly policy officials and representatives from the water management and agricultural sectors at the national level. In the WaL program, the local members of the design teams and the city government, such as the Semarang Planning Agency, played an important role in the translation of the conceptual design to the set-up of local meetings and organization of community engagement. This is related to the essential condition to involve local stakeholders such as local communities, NGOs, universities, and different interest groups in the cocreation of flood resilience solutions. However, the results indicated that the involvement of local-based NGOs was limited. This is partly due to their limited capacities to take part in the design contest and to give input for the climate resilience conceptual design process [39]. There was also a lack of participation from local parties representing the financial and private sectors during the resilience-by-design process.

\subsection{Position Rules}

Both the MDP and the WaL program were similar in enabling the involved actors to assert the 'promoter' and the 'facilitator' roles for planning for inclusive flood resilience. The first similarity is that both programs promoted the reframing of flood problems and the development of proactive and integrated flood risk management strategies. In Vietnam, the Dutch consultants and Vietnamese academics and retired civil servants helped to create new solutions and to reframe the existing flood and climate challenges of the Mekong Delta. In this context, the MDP working group leader, Royal HaskoningDHV, stated: "Some of them are already retired which for them is an advantage because they are freer to say what they want and what they think." In the case of the WaL program, both the international and the local design members delivered the analysis of vulnerabilities in the local context and presented flood resilience strategies including nature-based measures, ecological restoration, community preparedness, and rainwater harvesting and retention [53]. The second similarity is that both international resilience programs enabled the participants to facilitate the collaboration process together with international development partners and organizations. In the case of the MDP, the program promoted the organization of the Mekong Delta Forum, a communication platform between the Vietnamese government, international donors, financial institutions, and development organizations to encourage these actors to collectively adopt the recommendations from the MDP [54]. The Water Secretary at the Dutch Embassy in Hanoi explained: "The development partners had been in the driver's seat for the Delta Forum in 2015 and 2016, but now suddenly the [Vietnamese] government took that position and further elaborated it with the input from the development partners." The WaL program enabled the design teams to facilitate the collaboration between the local design members with the international design team members; particularly, the design lead played a crucial role in facilitating the relations 
within the teams and with international partners. As the design lead of the 'One Semarang' team stated: "There is a really strong social component. I think that's what's great about the Water as Leverage program is that you also building of social relation."

A difference is that the MDP created an essential condition for connecting the integrated solutions to the planning and policy-making process, while the WaL program focused more on facilitating the collaboration with local policy actors and stakeholders. Based on this, the participants in the MDP had more 'connector' roles and capacities to also implement the developed flood solutions. The Ministry of Agriculture and Rural Development (MARD), which is responsible for developing and executing the water resources and agriculture planning projects in Vietnam, oversaw the realization of the MDP. As the MDP working group leader stated: "MARD is way more powerful [than other ministries and government agencies] because they are responsible for agriculture, which in Vietnam means food security, and for the water management system, irrigation, flood protection, river works, and salinization issues." This was different in the WaL program. The local government in the WaL program had fewer connecting roles with regard to the actual policy implementation. The mobilization of funding for the implementation of the strategic climate resilience proposals required engagement with the national government. As a local member of 'One Semarang' said: "What the design teams produce required national government support because unfortunately in Indonesia, city governments don't have a lot to say." The local members of the design teams and the local government partners involved in the WaL program in Semarang created the local 'WaL Taskforce' to strengthen their connecting roles. The role of this local WaL taskforce was to ensure the continuation of the program, and to organize communication with the national and regional governmental decision-makers for the implementation of the design proposals [43].

\subsection{Choice Rules}

The similarity with regard to the choice rules was that both the MDP and the WaL program supported conditions for stimulating the learning process among the participants related to the development and implementation of inclusive flood resilience strategies. The MDP created the condition for Vietnamese policy makers to adopt and experiment with a new flood resilience strategy that was based on the 'agro-industry' strategic recommendation. This recommendation stimulated policy actors to diversify and develop flexible adaptation approaches, such as no-regret measures, (short-term) priority measures and mid- to long-term measures based on scenario planning and analysis [54]. Similarly, the WaL program promoted the co-creation of transformative and inclusive flood resilience visions and solutions, which materialized in six strategic climate resilience proposals. As a local member of the 'Cascading Semarang' team explained: "The initial idea came from the international experts of the design teams and the local partner needs to interpret and translate the ideas fitting with particularities of Indonesian context". In addition, the WaL program created conditions for capacity building within the local governmental agencies and stakeholders during the design-based research and the conceptual design of the strategic climate resilience proposals. A local member of the 'Cascading Semarang' stressed: "It is also important to improve the capacity of the stakeholders because, at the end of the day, they (the local stakeholders) will run or implement or contribute to the process. It's not the international persons".

The major difference between how these two programs approached the choice rules relates to the development of integrated and proactive long-term flood risk management measures. The MDP did not indicate specific measures regarding the flood resilience strategies. The output of the MDP was strategic recommendations supported by a scenario analysis of the Mekong delta. It thus provided broad strategic choices and various policy paths towards resilience delta management. These recommendations were adopted by regional and provincial governments to develop more concrete resilient flood risk management measures. For instance, Tra Vinh Province's rain and floodwater harvesting and storage proposal to reduce groundwater exploitation was developed based on the align- 
ment of local initiatives with the MDP's recommendations. By contrast, the WaL program delivered more concrete resilience proposals visualizing specific types of flood resilience strategies. The WaL program therefore provided clearer and more specific solutions for the development and implementation of flood resilience initiatives for the city. This is evidenced in the development of the climate resilience solutions such as the proposals for 'Spongy Mountain Terrace' and 'Rechanneling the City', thereby focusing on integrating spatial measures in the city's flood resilience management [52].

\subsection{Scope Rules}

With regard to the scope rules, a key similarity between the MDP and the WaL program was the two main anticipated outcomes in adaptability and transformability envisioned by both international resilience programs. First, both programs promoted initiatives and solutions for flood adaptation and recovery, and second, they promoted societal learning and fostering change and innovation. To achieve adaptability to climate risks, the MDP suggested the transition from agricultural development to accommodating saltwater intrusion, and supporting investments in aquaculture and nature-based flood storage, which would have multiple social and ecological benefits [55]. The World Bank's appraisal document for the funding of the MDP implementation stated: "The MDP calls for policy change of avoiding, and, where possible, in the long run, reversing the embankment of the floodplains" [56]. The strategic climate resilience proposals from the WaL program are aimed at capacity-building for the adaptation of the city and among vulnerable communities. The 'Spongy Mountain Terrace', 'Water-Neutral Industry', and 'Feeding Industry' proposals focused on the spatial measures for mitigating flood risks and increasing water supply. As the design team lead of 'Cascading Semarang' stated: "In my mind, it is almost impossible not to address that in an inclusive, and a holistic kind of viewpoint or approach." With regard to the transformability, the MDP promoted the integrated approach in the institutional conditions for flood adaptation. An involved academic from Can Tho University said: "It's rather sectoral planning [fragmentation of agencies in delta management] whilst the Mekong Delta Plan is integrated planning combining different fields (in water management and flood risk management)." To achieve the transformative outcome in flood resilience planning process, the WaL program induced societal learning through a coalition of designers and design teams, local government, universities and NGOs. The WaL program, for instance, promoted critical discussions on the existing water challenges and climate vulnerabilities and created a narrative of flood adaptation for driving the collective efforts for inclusive flood resilience [39].

The WaL program differed from the MDP because it emphasized robustness in flood protection, along with adaptability and transformability as essential conditions in the development of climate resilience proposals; therefore, the strategic climate resilience proposals also specifically addressed flood safety and protection. To give an example, the strategic climate resilience proposal includes the 'Rechanneling the City' program, which focuses on the prevention of water discharges while improving the spatial quality of the inner-city waterfront [53]. In addition, the WaL program highlighted the inclusive dimension in transformability, especially among vulnerable communities. Proposals such as 'Network of resilient Kampungs', for instance, aimed to enhance local community engagement and to increase flood awareness among the community members. This proposal, developed by 'One Semarang', was based on consultation and engagement with local communities, and introduced community participatory tools and guidelines for community involvement in the development and implementation of resilience solutions [53]. Therefore, inclusive outcomes are more evidenced in the WaL case due to the essential condition to engage local communities openly and collaboratively.

\subsection{Aggregation Rules}

Both the MDP and the WaL program similarly attempted to enable a cocreation process for stimulating local ownership of flood resilience solutions. The formulation of the MDP 
was a modification of the Dutch delta management approach, which was translated to the Vietnamese interests and ambitions in delta management. Therefore, the focus of the plan shifted from water and climate risk to agriculture and economic development $[45,50,57]$. The WaL program also enabled the cocreation of solutions between the multidisciplinary design teams and local stakeholders. In addition, both programs also attempted to integrate the develop flood resilience solutions in the formal planning process. The integration of the MDP in formal policy plans was particularly evidenced in Government Resolution 120 on 'Sustainable and climate-resilient development of the Mekong Delta' [52,58]. For the WaL program, members of the design teams were also involved in embedding the concepts and solutions from the strategic climate resilience proposals in Semarang's midterm spatial plan. As a member of the 'Cascading Semarang' team explained: "We are now actually strengthening the capacities the province on the water-related issues of industries and trying to involve them [the provincial governments] in the acceptance of the ideas of Water as Leverage."

An important difference in the aggregation rules was that of the condition to involve participants, policy makers and local communities in decision-making. The development and implementation of the MDP was an expert-driven and top-down processes based on the strategic interests of the Vietnamese national government and international experts. As the former Water Secretary at the Dutch Embassy in Hanoi stated: "You have got to realize that in Vietnam if you don't involve the top-level, nothing is going to happen. So, it is very simple that you have to work with the official government especially at the ministry level." As a result, the MDP was able to influence the national, provincial, and local water planning projects, which led to a change of mind among policy makers [51]. In contrast, the WaL program promoted the importance of a bottom-up process and local coalition building based on consultation with local communities, the city government, and NGOs [46]. As the design lead of 'Cascading Semarang' stated: "We as designers are very much used to working with a lot of stakeholders. We are very much used to working with a lot of different stakeholders, and understanding them and trying to integrate them." At the same time, the community members were reluctant to participate in the consultation process because of the uncertainties and dynamics of the process.

\subsection{Information Rules}

The similarity between how the MDP and the WaL program approached the information rules are related to the essential conditions for integrating scientific insights and innovative ideas in resilience building efforts and raising flood awareness. Both programs presented new solutions to address flood vulnerabilities and to raise awareness of the complex environmental and water challenges of the local context. The MDP offered the framing of the climate-induced problems of the Mekong Delta and recommended a strategic vision for delta management based on scientific insights and expert analysis. These insights and information were relayed to the participants in the Mekong Delta Forum [49]. The Mekong Delta Forum also helped to translate and advocate the MDP insights among regional and provincial government officials, such as the need for collaboration beyond their administrative boundaries $[15,51]$. The WaL program supported the design team in conducting design-based research to explore the vulnerabilities of the urban context and to identify possible proactive and integrated resilience solutions. Whilst conducting our research we found, however, that both programs were less focused on integrating local insights and knowledge into the flood solutions. The essential condition to the integration of local knowledge and existing experience in both programs should be strengthened.

There are two main differences in the approaches of both programs with regard to the information rules. The first difference relates to the essential condition of open communication and local dialogues. In this context, the WaL program focused more on direct communication and interaction with communities for building trust and sharedunderstanding with local stakeholders, especially at the city level. As the coordinator of the WaL program stated: “The starting point was the development of the solutions together 
(with the local stakeholders) instead of a solution that was defined by us." The design lead of 'One Semarang' added: "That is a constant process of iteration and feedback. You start with trying to understand what's going on, and then try to ask around." The key activities for collaboration and communication between the local stakeholders were the design-based research and the cocreation of solutions. A local member of 'One Semarang' stated: "I think we value a lot in being able to be quite thorough in our engagement with our stakeholders and communities and getting the information, but also in being able to translate this to what it means for a bigger picture, conceptualizing these things in design terms." The second difference relates to integrating new knowledge and ideas, in particular the translation and communication of Dutch delta management knowledge, which are more evident in the MDP case. The recommendations regarding 'integrated delta management' and 'living with the floods' for restoring the natural flood dynamic were influenced by Dutch delta management $[57,59]$. In the WaL case, despite the many design team members from Dutch design firms, consultancy companies and other agencies that participated in the WaL program, the design of the strategic climate solutions was less focused on knowledge translation or adaptation of Dutch delta management as new knowledge and policy ideas.

\subsection{Payoff Rules}

The inclusive flood resilience solutions from the MDP and WaL program similarly required external funding. Both the MDP and the WaL program, however, were unable to secure the required funding for the project implementation. The programs only financed the initial planning process and the development of innovative concepts and solutions. The focus of both programs was to create the essential conditions for identifying and supporting the mobilization of funding for project financing and implementation. To this end, the programs helped local participants develop the financial proposals and linked the local stakeholders with international development organizations and international financial institutions for acquiring international funding. In the MDP case, the program involved the World Bank to stimulate the Vietnamese government to adopt the insights and recommendations of the plan. As a result, MARD was able to acquire international funding through international development financial loans, the Mekong Delta Integrated Climate Resilience and Sustainable Livelihood Project (ICRSL), and 376 million USD from the World Bank [60]. The set-up of the WaL program was to provide opportunities for international financial institutions to engage in the resilience-by-design process by giving the design teams insight into the financial criteria.

Furthermore, both programs tried to ensure social and ecological outcomes from the project implementation. In the MDP case, the funding from the World Bank created conditions to ensure social and environmental outcomes such as requiring consultation with international experts for the development and implementation of the delta and water management projects [56]. The Government Resolution 120, for instance, specifically stated the strategic partnership with the Netherlands for technological assistance and investment in the sustainable development of the Mekong Delta [58]. In the WaL program, multidisciplinary design teams were granted Intellectual Property Rights (IPR) by the program to ensure their continuing role in the further development of the solutions [43]. This condition aims to ensure continuous design team roles that could incentivize the design firms, consultants, and organizations to secure the integrated social, ecological, and economic outcomes of the project implementation.

The major difference in the payoff rules was the current state of funding opportunities and mobilization. The MDP, which began earlier than the WaL program, received international loans from the World Bank in 2017 after the plan was launched in 2013. The Mekong Delta Coordinator at the Dutch Ministry of Infrastructure and Water Management stated: "The World Bank and the Asian Development Bank were committed. They had their targets on putting money in the market, and then the money should be spent according to the [MDP] delta principles." At the time of writing, the funding was yet to be determined 
for the project implementation for the WaL program. The design teams still have to work with the national government for approval and support regarding the climate resilience proposals. As the UN-Habitat Design Lab lead, one of the international partners of the WaL program, stated: "In Semarang, it took a long time to engage the local authorities because, in Indonesia, everything needs to be negotiated at the national level too, so these two processes were not in sync". The design team and the city government were also working on project proposals to access different financial sources such as the Dutch government program Develop2Build and the World Bank's National Urban Development Project in Indonesia [61]. The materialization of the various design proposals in the project planning and implementation, that is, embedding the solutions in the local and national institutional contexts, is yet to be seen.

\section{Discussion: Strengths, Weaknesses, and Ways Forward}

Using the IAD framework to structure the comparative analysis enabled us to specify the essential conditions for the in-depth analysis of the institutional conditions required for inclusive flood resilience planning (see Table 2). According to our analysis of the rulesin-use, several institutional strengths and weaknesses were identified in the institutional arrangements of both the MDP and the WaL program.

With regard to institutional strengths, we found that the MDP had stimulated essential conditions, particularly relating to the position rules, the aggregation rules and the payoff rules. The MDP was able to involve the national government and international financial institutions in securing and enabling project financing and implementation. The program also stimulated international cooperation for mobilizing both funding and technical support, which would be essential for the implementation of the MDP's strategic resilience recommendations. In comparison to the MDP, the implementation of the WaL program demonstrated institutional strengths in the boundary rules, the choice rules, and the scope rules. The WaL program introduced a resilience-by-design process as an essential condition to connect a wide range of experts, designers, and consultants with local policy makers, academics, and other stakeholders. In this way, the program created an enabling environment for the cocreation of context-specific flood resilience proposals, thereby addressing the anticipated robustness, adaptability, and transformability outcomes in flood risk management. Moreover, the developed strategic climate resilience proposals communicated a shared vision and commitment of the coalition between international experts and designers and local stakeholders for planning toward inclusive flood resilience. The results also showed that both programs emphasized the use of scientific analysis and expert knowledge as an essential condition in the information rules, that is, those related to Dutch delta management (for the MDP) and international examples and experience (in the case of the WaL program).

By comparing the two cases, several institutional weaknesses in each case were identified. For the MDP case, we found that, like the institutional strengths, the institutional weaknesses related in particular to the position rules, the aggregation rules, and the payoff rules. There was limited consultation with local stakeholders in identifying potential flood strategies and solutions. The decision-making was mainly based on communication and involvement with the national government and international financial organizations and international development organizations. Thus, there was a lack of willingness and capacity at the regional and provincial levels to implement the recommendations of the MDP in the local planning practice; this was also found by previous authors $[49,52]$. Despite the ability to secure funding for the MDP, there were uncertainty and ambiguity in funding determinants and arrangements to support the implementation of the MDP. Consequently, it took several years for the involved participants to adopt the ideas from the MDP, and this process had to be supported by international development partners. For the WaL program, the institutional weaknesses could also be identified in the position rules, the aggregation rules, and the payoff rules. The WaL program did not approach the national government in the early planning phase or the cocreation of resilience solutions. As a 
result, the WaL program partners were mainly the city government and city planning agencies. However, the created solutions required integrating flood resilience policy making at different regional and national administrative levels, as well as the coordination and approval of the national government. Furthermore, the results show that in the institutional arrangements of both programs there was little integration of local knowledge and existing resilience initiatives. The integration of local knowledge is, however, relevant for stimulating local ownership and willingness to adopt the flood resilience solutions in local planning practice.

Based on our comparative institutional analysis and the overview of institutional strengths and weaknesses, several general recommendations can be formulated for international resilience programs. These recommendations link to the development of inclusive flood resilience solutions, the integration of the solutions in the formal policy context, and project financing and implementation. First, regarding the solutions, the recommendations could be drawn from our analysis of the boundary rules, scope rules and information rules. The inclusive engagement of diverse actors with willingness and interest to engage in international policy lessons, ideas and solutions from both existing resilience networks and other new policy networks is important. International resilience programs should inclusively involve local actors in developing the program to tailor it to the specific institutional conditions. The international resilience programs should enable the actors with fewer resources and capacities to engage in the resilience planning, policy learning, and international collaboration. In relation to the scope roles, the solutions should not only aim for initiatives to strengthen robustness and adaptability. The enabling environment should also allow for transformability. The structure of the program should, therefore, promote capacity building among policy makers and practitioners and continuous learning for societal change and innovation. Finally, in relation to the information rules, an essential condition is to enable open communication and dialogue between local participants and partners to integrate local knowledge, insights, and experience in the solution cocreation process.

The importance of aligning resilience solutions with the formal institutional context can be explained on the basis of the position rules, choice rules, and aggregation rules. Based on the position rules, this alignment requires the participants taking up the connector role as an essential institutional condition. This concerns, especially, the engagement between the participants and the local and national decision-makers. Based on the choice rules, an essential institutional condition is to integrate the inclusive flood resilience strategies in a broader policy agenda, especially for addressing the socioecological vulnerabilities among low-income communities. These conditions link to the aggregation rules suggesting that international resilience programs should identify different policy windows for alignment of the resilience solutions; for instance, in the city's resilience strategy and global agenda including the United Nations Sustainable Development Goals.

Lastly, recommendations for implementation include the essential conditions relating to the payoff rules and the choice rules. With regard to the payoff rules, we found that explicit communication and certainty in funding determinants could strengthen the willingness and motivation among policy makers to develop and implement flood resilience proposals. Likewise, uncertainty of funding and formalization of resilience proposals could demotivate participants to contribute to the process. While international funding was vital for the implementation of the flood resilience solutions in our case studies, other modes of funding mobilization, such as partnerships with and contribution of private sectors, should also be promoted. In line with the choice rules, our analysis also suggests that it is relevant to stimulate local ownership, acceptance, and the willingness to approach local and national funders. Although engagement with international programs and experts could foster new ideas and solutions, the continuity and sustainability of the flood resilience ambitions rely on shared local ownership and willingness to take up, finance, and implement solutions by local and national policy actors. 


\section{Conclusions}

This paper analyzed the institutional conditions that enabled the development and implementation of inclusive flood resilience strategies and studied how international resilience programs could promote these conditions. To this end, we developed an analytical framework based on the rules-in-use that are part of the IAD framework. Our findings showed that the international resilience programs, which were initiated by the Netherlands, created opportunities to enable various essential institutional conditions in the national and local planning context. It is evident that inclusive engagement with policy actors, open dialogue and communication about the prospects and funding conditions, the integration of scientific analysis for problem reframing and exploration, and the design and cocreation of solutions, are key factors for success. The ability to translate these solutions into formal plans and project implementation relies heavily on the formal positions of the involved actors and the involvement of international funders and international development organizations.

With this study, we contribute to a better understanding of essential institutional conditions for supporting national and local flood resilience planning processes in a developing country context. The combination of institutional conditions based on rules-in-use is important for the cocreation of solutions, the alignment of these solutions in the institutional contexts, and the activation of the implementation process. Recognizing the potential of further development and replication of similar types of resilience programs in other developing countries, such as the replication of the resilience-by-design process in Africa and other parts of the world [62], this study suggests that local policy actors should be engaged in setting up the program and adapting the program to the local specific context. This paper further highlights the inclusiveness dimension in the characterization of the essential conditions, such as the inclusive involvement of actors in the decision-making and cocreation process, ensuring socially equitable outcomes and fairness in flood resilience building and recognizing local interests, knowledge, and experience. To conclude, this paper calls for greater attention to the institutional dimension of international resilience programs, particularly the interaction for cocreating solutions and the translation of international solutions to the local implementation process. We suggest that future research could explore different governance strategies for combining international experience with local knowledge, different types of collaborative learning programs among countries in the same region, and shared institutional frameworks for the transition to inclusive flood resilience financing and implementation at both the international and local scales.

Author Contributions: The paper was written by N.L. based on the results obtained from his research, which was designed and conducted under the close supervision of M.v.d.B., J.A.; conceptualization and development of frameworks were carried out by N.L., M.v.d.B., J.A.; editing and revising were done by N.L., M.v.d.B., J.A. All authors have read and agreed to the published version of the manuscript.

Funding: This research received no external funding.

Institutional Review Board Statement: Not applicable.

Informed Consent Statement: Not applicable.

Data Availability Statement: Not applicable.

Conflicts of Interest: The authors declare no conflict of interest.

\section{Appendix A}

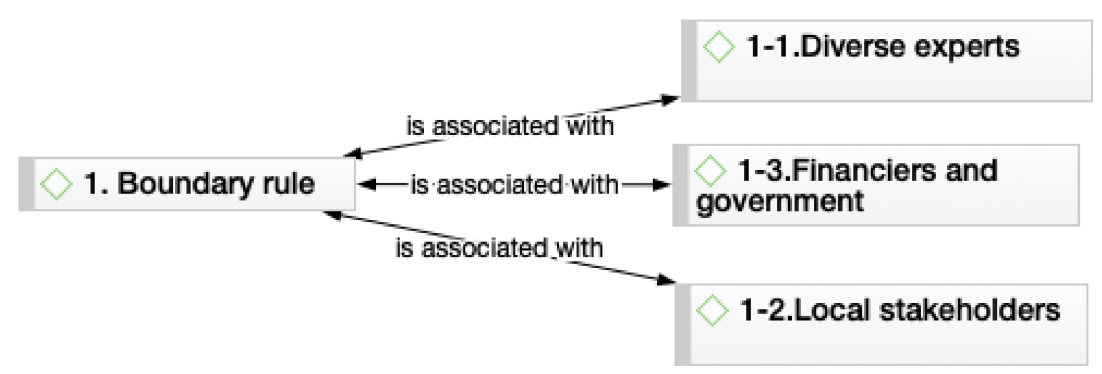



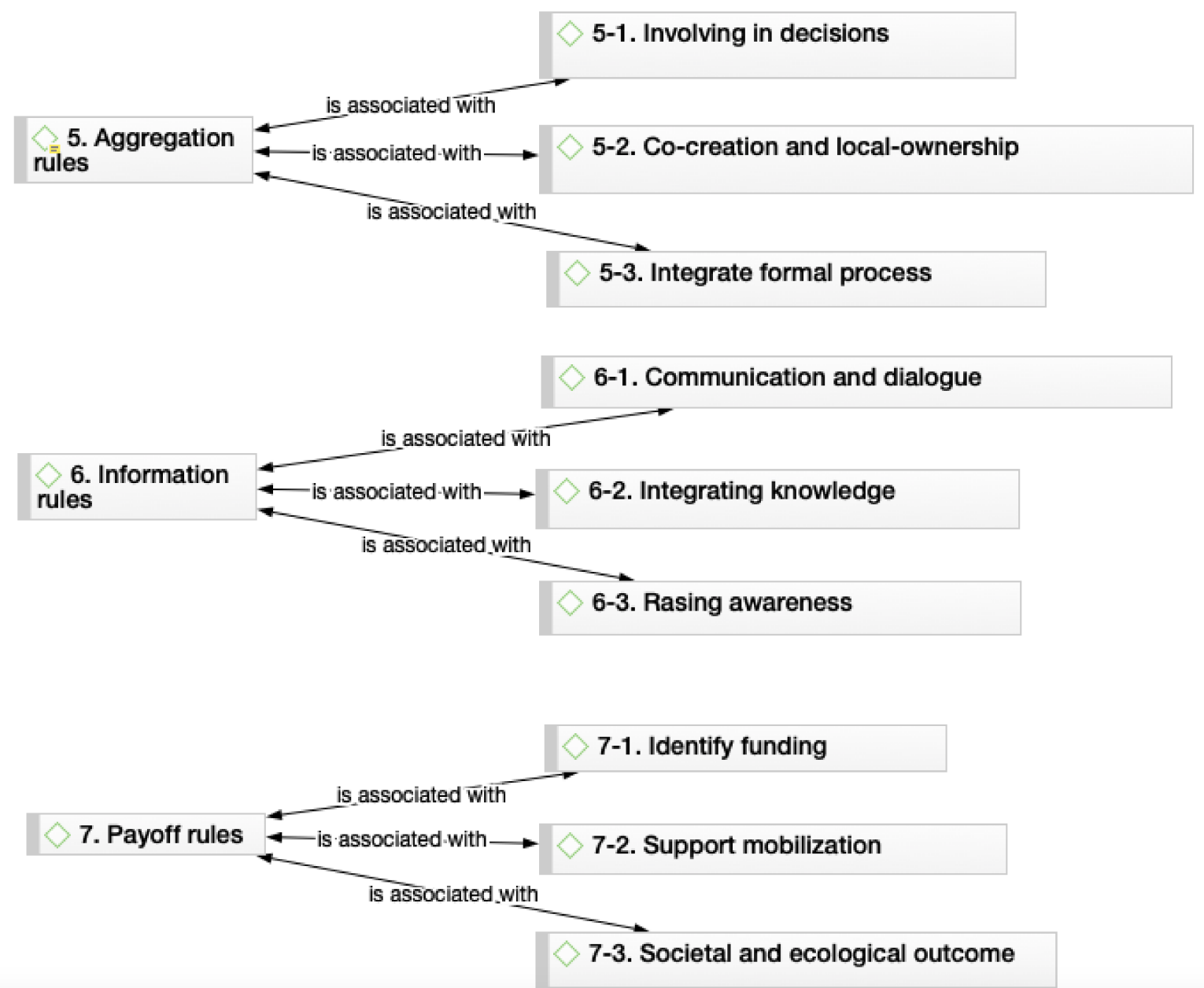

Figure A1. Code networks.

\section{References}

1. Vinke, K.; Schellnhuber, H.J.; Coumou, D.; Geiger, T.; Glanemann, N.; Huber, V.; Knaus, M.; Kropp, J.; Kriewald, S.; Laplante, B. A Region at Risk: The Human Dimensions of Climate Change in Asia and the Pacific; Asian Development Bank: Manila, Philippines, 2017.

2. Dai, L.; Wörner, R.; Van Rijswick, H.F.M.W. Rainproof cities in the Netherlands: Approaches in Dutch water governance to climate-adaptive urban planning. Int. J. Water Resour. Dev. 2018, 34, 652-674. [CrossRef]

3. Restemeyer, B.; Woltjer, J.; Van Den Brink, M. A strategy-based framework for assessing the flood resilience of cities-A Hamburg case study. Plan. Theory Pract. 2015, 16, 45-62. [CrossRef]

4. Liao, K.-H. A theory on urban resilience to floods-A basis for alternative planning practices. Ecol. Soc. 2012, 17, 4. [CrossRef]

5. Hegger, D.L.T.; Driessen, P.P.J.; Wiering, M.; Van Rijswick, H.F.M.W.; Kundzewicz, Z.W.; Matczak, P.; Crabbé, A.; Raadgever, G.T.; Bakker, M.H.N.; Priest, S.J.; et al. Toward more flood resilience: Is a diversification of flood risk management strategies the way forward? Ecol. Soc. 2016, 21, 4. [CrossRef]

6. Wesselink, A.; Warner, J.; Syed, M.A.; Chan, F.; Tran, D.D.; Huq, H.; Huthoff, F.; Le Thuy, F.; Le Thuy, N.; Pinter, N. Trends in flood risk management in deltas around the world: Are we going 'soft'. Int. J. Water Gov. 2015, 3, 25-46.

7. Handayani, W.; Fisher, M.R.; Rudiarto, I.; Setyono, J.S.; Foley, D. Operationalizing resilience: A content analysis of flood disaster planning in two coastal cities in Central Java, Indonesia. Int. J. Disaster Risk Reduct. 2019, 35, 101073. [CrossRef]

8. Kuang, D.; Liao, K.-H. Learning from floods: Linking flood experience and flood resilience. J. Environ. Manag. 2020, $271,111025$. [CrossRef]

9. Driessen, P.P.J.; Hegger, D.L.T.; Kundzewicz, Z.W.; Van Rijswick, H.F.M.W.; Crabbé, A.; Larrue, C.; Matczak, P.; Pettersson, M.; Priest, S.; Suykens, C.; et al. Governance strategies for improving flood resilience in the face of climate change. Water 2018, 10, 1595. [CrossRef]

10. Rosenzweig, B.R.; McPhillips, L.; Chang, H.; Cheng, C.; Welty, C.; Matsler, M.; Iwaniec, D.; Davidson, C.I. Pluvial flood risk and opportunities for resilience. Wiley Interdiscip. Rev. Water 2018, 5, e1302. [CrossRef] 
11. Alexander, M.; Priest, S.; Mees, H. A framework for evaluating flood risk governance. Environ. Sci. Policy $2016,64,38-47$. [CrossRef]

12. Marks, D. The urban political ecology of the 2011 floods in Bangkok: The creation of uneven vulnerabilities. Pac. Aff. 2015, 88, 623-651. [CrossRef]

13. Mobilia, M.; Longobardi, A. Smart stormwater management in urban areas by roofs greening. In Computer Vision; Springer Science and Business: Berlin/Heidelberg, Germany, 2017; Volume 10406, pp. 455-463.

14. Marks, D.; Elinoff, E. Splintering disaster: Relocating harm and remaking nature after the 2011 floods in Bangkok. Int. Dev. Plan. Rev. 2020, 42, 273-294. [CrossRef]

15. Lebel, L.; Anderies, J.M.; Campbell, B.; Folke, C.; Hatfield-Dodds, S.; Hughes, T.P.; Wilson, J. Governance and the capacity to manage resilience in regional social-ecological systems. Ecol. Soc. 2006, 11. [CrossRef]

16. Alexander, M.; Doorn, N.; Priest, S. Bridging the legitimacy gap-Translating theory into practical signposts for legitimate flood risk governance. Reg. Environ. Chang. 2018, 18, 397-408. [CrossRef]

17. Molenveld, A.; Van Buuren, A. Flood risk and resilience in the Netherlands: In search of an adaptive governance approach. Water 2019, 11, 2563. [CrossRef]

18. Ostrom, E. Beyond Markets and States: Polycentric Governance of Complex Economic Systems. Am. Econ. Rev. 2010, 100, 641-672. [CrossRef]

19. Ostrom, E. Background on the institutional analysis and development framework. Policy Stud. J. 2011, 39, 7-27. [CrossRef]

20. Clement, F. Analysing decentralised natural resource governance: Proposition for a "politicised" institutional analysis and development framework. Policy Sci. 2009, 43, 129-156. [CrossRef]

21. Vitale, C.; Meijerink, S.; Moccia, F.D.; Ache, P. Urban flood resilience, a discursive-institutional analysis of planning practices in the Metropolitan City of Milan. Land Use Policy 2020, 95, 104575. [CrossRef]

22. Anderies, J.M. Embedding built environments in social-ecological systems: Resilience-based design principles. Build. Res. Inf. 2014, 42, 130-142. [CrossRef]

23. Ostrom, E.; Gibson, C.; Shivakumar, S.; Andersson, K.J.S.S.I.T.E. Aid, incentives and sustainability. An analysis of development co-operation. In SIDA Studies in the Evaluation; Sida Swedish International Development Agency: Stockholm, Sweden, 2002; Volume 2.

24. Andersson, K. Motivational dilemmas in collaborative learning activities: The case of the Swedish International Development Cooperation Agency (SIDA). Public Adm. Dev. 2009, 29, 341-351. [CrossRef]

25. Gersonius, B.; Van Buuren, A.; Zethof, M.; Kelder, E. Resilient flood risk strategies: Institutional preconditions for implementation. Ecol. Soc. 2016, 21, 4. [CrossRef]

26. Wiering, M.; Kaufmann, M.; Mees, H.; Schellenberger, T.; Ganzevoort, W.; Hegger, D.; Larrue, C.; Matczak, P. Varieties of flood risk governance in Europe: How do countries respond to driving forces and what explains institutional change? Glob. Environ. Chang. 2017, 44, 15-26. [CrossRef]

27. Mullenite, J. Resilience, political ecology, and power: Convergences, divergences, and the potential for a postanarchist geographical imagination. Geogr. Compass 2016, 10, 378-388. [CrossRef]

28. Furedi, F. Fear and security: A vulnerability-led policy response. Soc. Policy Adm. 2008, 42, 645-661. [CrossRef]

29. Keil, R. Progress report—urban political ecology. Urban Geogr. 2005, 26, 640-651. [CrossRef]

30. Hurk, M.V.D.; Mastenbroek, E.; Meijerink, S. Water safety and spatial development: An institutional comparison between the United Kingdom and the Netherlands. Land Use Policy 2014, 36, 416-426. [CrossRef]

31. Spijkerboer, R.; Zuidema, C.; Busscher, T.; Arts, J. Institutional harmonization for spatial integration of renewable energy: Developing an analytical approach. J. Clean. Prod. 2019, 209, 1593-1603. [CrossRef]

32. Hijdra, A.; Woltjer, J.; Arts, J. Troubled waters: An institutional analysis of ageing Dutch and American waterway infrastructure. Transp. Policy 2015, 42, 64-74. [CrossRef]

33. Van Geet, M.T.; Lenferink, S.; Arts, J.; Leendertse, W. Understanding the ongoing struggle for land use and transport integration: Institutional incongruence in the Dutch national planning process. Transp. Policy 2019, 73, 84-100. [CrossRef]

34. Ostrom, E. Coping with tragedies of the commons. Annu. Rev. Politi. Sci. 1999, 2, 493-535. [CrossRef]

35. Ostrom, E.; Basurto, X. Crafting analytical tools to study institutional change. J. Inst. Econ. 2010, 7, 317-343. [CrossRef]

36. Davoudi, S. Interface introduction. Resilience: A bridging concept or a dead end. Plan. Theory Pract. 2012, 13, 299-333. [CrossRef]

37. Sörensen, J.; Persson, A.; Sternudd, C.; Aspegren, H.; Nilsson, J.; Nordström, J.; Jönsson, K.; Mottaghi, M.; Becker, P.; Pilesjö, P.; et al. Re-thinking urban flood management—time for a regime shift. Water 2016, 8, 332. [CrossRef]

38. Driessen, P.P.J.; Hegger, D.L.T.; Bakker, M.H.N.; Van Rijswick, H.F.M.W.; Kundzewicz, Z.W. Toward more resilient flood risk governance. Ecol. Soc. 2016, 21, 53. [CrossRef]

39. Laeni, N.; Brink, M.; Busscher, T.; Ovink, H.; Arts, J. Building local institutional capacities for urban flood adaptation: Lessons from the water as leverage program in Semarang, Indonesia. Sustainability 2020, 12, 10104. [CrossRef]

40. Brink, M.V.D.; Edelenbos, J.; Brink, A.V.D.; Verweij, S.; Van Etteger, R.; Busscher, T. To draw or to cross the line? The landscape architect as boundary spanner in Dutch river management. Landsc. Urban Plan. 2019, 186, 13-23. [CrossRef]

41. Folke, C.; Carpenter, S.R.; Walker, B.; Scheffer, M.; Chapin, T.; Rockström, J. Resilience thinking: Integrating resilience, adaptability and transformability. Ecol. Soc. 2010, 15. [CrossRef] 
42. Pahl-Wostl, C.; Arthington, A.; Bogardi, J.; Bunn, S.E.; Hoff, H.; Lebel, L.; Nikitina, E.; Palmer, M.; Poff, L.N.; Richards, K.; et al. Environmental flows and water governance: Managing sustainable water uses. Curr. Opin. Environ. Sustain. 2013, 5, 341-351. [CrossRef]

43. Laeni, N.; Ovink, H.; Busscher, T.; Handayani, W.; Brink, M.V.D. A transformative process for urban climate resilience: The case of water as leverage resilient cities Asia in Semarang, Indonesia. In Climate Resilient Urban Areas: Governance, Design and Development in Coastal Delta Cities; Springer: Berlin/Heidelberg, Germany, 2021; pp. 155-173.

44. Lebel, L.; Manuta, J.B.; Garden, P. Institutional traps and vulnerability to changes in climate and flood regimes in Thailand. Reg. Environ. Chang. 2010, 11, 45-58. [CrossRef]

45. Hasan, S.; Evers, J.; Zegwaard, A.; Zwarteveen, M. Making waves in the Mekong Delta: Recognizing the work and the actors behind the transfer of Dutch delta planning expertise. J. Environ. Plan. Manag. 2019, 62, 1583-1602. [CrossRef]

46. Government of the Netherlands. Factsheet Water as Leverage; Ministry of Infrastructure and Water Management and Ministry of Foreign Affairs: The Hague, The Netherlands, 2019.

47. One Resilient Semarang. One Resilient Semarang Volume 1 Research, Analysis and Engagement (Draft Report-For Workshop Purposes); Water as Leverage; One Architecture and Urbanism: Amsterdam, The Netherlands, 2018.

48. Cascading Semarang. Cascading Semarang Steps to Inclusive Growth Phase One Report; MLA+: Rotterdam, The Netherlands, 2018.

49. Korbee, D.; Quan, N.H.; Hermans, L.; Long, P.H. Navigating the bureaucracy: An analysis of implementation feasibility for the Mekong Delta Plan, Vietnam. J. Environ. Plan. Manag. 2019, 62, 1545-1561. [CrossRef]

50. Laeni, N.; Brink, M.A.V.D.; Trell, E.M.; Arts, E.J.M.M. Going Dutch in the mekong delta: A framing perspective on water policy translation. J. Environ. Policy Plan. 2021, 23, 16-33. [CrossRef]

51. Seijger, C.; Hoang, V.T.M.; Van Halsema, G.; Douven, W.; Wyatt, A. Do strategic delta plans get implemented? The case of the mekong delta plan. Reg. Environ. Chang. 2019, 19, 1131-1145. [CrossRef]

52. Vo, H.T.M.; Van Halsema, G.; Seijger, C.; Dang, N.K.; Dewulf, A.; Hellegers, P. Political agenda-setting for strategic delta planning in the mekong delta: Converging or diverging agendas of policy actors and the mekong delta plan? J. Environ. Plan. Manag. 2019, 62, 1454-1474. [CrossRef]

53. Water as Leverage. Water as Leverage Team Approach [Factsheet]; Leverage, W.A., Ed.; Enterprise Agency: The Hague, The Netherlands, 2019.

54. The World Bank. Mekong Delta Forum. Available online: http://www.worldbank.org/en/news/press-release/2015/02/ 02/mekong-delta-forum-builds-momentum-for-coordinated-action-to-improve-resilience-to-climate-change-and-enhanceshared-prosperity (accessed on 10 December 2019).

55. Government of The Netherlands; Government of Vietnam. Mekong Delta Plan; Government of Vietnam: Hanoi, Vietnam, 2013.

56. The World Bank. International Development Association Project Appraisal Document on a Proposed Credit of SDR 213.0 Million to the Socialist Republic of Vietnam for a Mekong Delta Integrated Climate Resilience and Sustainable Livelihood Project; The World Bank: Washington, DC, USA, 2016.

57. Van Staveren, M.F.; Van Tatenhove, J.; Warner, J.F. The tenth dragon: Controlled seasonal flooding in long-term policy plans for the Vietnamese mekong delta. J. Environ. Policy Plan. 2017, 20, 267-281. [CrossRef]

58. Government of Vietnam. Resolution 120 on Sustainable and Climate-Resilient Development of the Mekong Delta; Government of Vietnam: Hanoi, Vietnam, 2018.

59. Weger, J. The vietnamization of delta management: The mekong delta plan and politics of translation in Vietnam. Environ. Sci. Policy 2019, 100, 183-188. [CrossRef]

60. Ministry of Agriculture and Rural Development. Mekong Delta Integrated Climate Resilience and Sustainable Livelihood Project; Ministry of Agriculture and Rural Development: Hanoi, Vietnam, 2017.

61. Water as Leverage. Water as Leverage Resilient Cities Asia. Available online: https://waterasleverage.org/ (accessed on 10 December 2019).

62. Lochhead, H. Resilience by design: Can innovative processes deliver more? Procedia Eng. 2017, 180, 7-15. [CrossRef] 